\title{
SISTEM REKOMENDASI COLLABORATIVE UNTUK PENYEWAAN DVD ONLINE DENGAN MENGGUNAKAN ITEM TO ITEM SIMILARITY MAPPINGS
}

\author{
Rocky Limandauw \\ Jurusan Teknik Informatika, Sekolah Tinggi Teknik Surabaya \\ rocky_limandauw@yahoo.co.id
}

\begin{abstract}
ABSTRAK
Film merupakan salah satu sarana hiburan yang disukai banyak orang. Namun sayangnya banyak orang yang memiliki waktu yang sangat terbatas. Masalah lain yang timbul adalah seorang pelanggan terkadang merasa bingung dalam menentukan film film yang akan disewa. Maka dari itu dibuat suatu website yang menyediakan fasilitas rekomendasi film untuk pelanggan, sehingga pelanggan mendapatkan refrensi untuk menentukan film film yang akan disewa dan bisa memesan melalui internet.

Terdapat berbagai macam cara / algoritma yang dapat digunakan dalam pemberian rekomendasi kepada pelanggan. Algoritma yang digunakan dalam pembangunan tugas akhir ini bernama Collaborative Recommendations Using Item to Item Similarity Mappings. Kata "Similarity" pada nama algoritma mengacu pada tabel yang akan dibentuk yang memetakan pasangan pasangan film yang ada dalam database, beserta nilai kemiripan pasangan film tersebut. Pelanggan akan diberikan rekomendasi film berdasarkan film film yang disukai oleh pelanggan tersebut. Kemudian akan dicari film film lain yang memiliki kemiripan dengan film film yang disukai pelanggan. Film hasil pencarian tersebut siap dijadikan sebagai bahan rekomendasi untuk pelanggan yang bersangkutan.

Website akan dikembangkan dengan menggunakan ASP.NET, dengan bahasa VB.NET sebagai front end. SQL Server akan digunakan sebagai back end, yang menyimpan data data website. DTS yang merupakan salah satu fasilitas pada SQL Server akan digunakan sebagai alat pembentuk tabel similar items yang dijadikan dasar dalam pemberian rekomendasi.
\end{abstract}

Kata Kunci : Web Server, Algoritma Collaborative Recommendations, Item Similarity Mappings.

ABSTRACT
Film is an example of many entertainment people liked. But unfortunately many people only have limited time. Another problem is that sometimes customers get confused in deciding which movie to rent. Therefore, a website that can provide a recommendation to the customer was developed, so that customers can get a reference to decide which movie to rent and order it via the internet.

There are many different ways or algorithms that can be used in providing recommendations to customers. Algorithm used in this final assignment is called Collaborative Recommendations Using Item to Item Similarity Mappings. The word "similarity" in the algorithm's name refers to the table that will be formed by mapping couple of films in the database, along with the similarity value of the films. Recommendations will be given to the customer based on movies liked by the customer. Then, another movie that has similarity with customer's favourite movie will be searched. After that, the search results are ready to become recommendation materials for the customer.

The Website will be developed by using ASP.NET, VB.NET language as a front end. The $S Q L$ Server will be used as a back end, to store data from the website. DTS is one of the feature in the SQL Server. It will be used as a tool to form the similar items table as a basis for providing the recommendations.

Kata Kunci : Web Server, Collaborative Recommendations Algorithm, Item Similarity Mappings. 


\section{PENDAHULUAN}

Persaingan dalam dunia perekonomian semakin ketat. Karena hal tersebut banyak perusahaan melakukan berbagai macam cara untuk meningkatkan omzet pendapatan dan penjualan mereka. Beberapa perusahaan bergerak selangkah lebih maju dengan melakukan promosi melalui media-media yang lebih dikenal dengan istilah iklan. Namun sayangnya, tidak semua perusahaan mampu melakukan hal tersebut, hal ini dikarenakan biaya yang harus dikeluarkan sangat mahal. Selain itu, dengan menggunakan iklan, sangat sulit untuk menjalin komunikasi antara perusahaan dengan pelanggan-pelanggannya.

Internet, merupakan sarana informasi yang sangat berkembang saat ini. Berbagai macam hal dapat dilakukan dengan menggunakan internet, seperti pencarian informasi, forum diskusi, sarana pendidikan, transaksi penjualan, dsb. Transaksi melalui internet merupakan salah satu manfaat yang penting dalam penggunaan internet, dimana seorang pembeli dapat berbelanja atau menyewa tanpa harus pergi ke suatu tempat tujuan untuk melihat barang-barang yang akan dibeli atau disewa, namun pembeli tersebut cukup memesan pada website yang bersangkutan, melakukan pembayaran dan barang akan dikirimkan ke alamat pembeli.

Film merupakan salah satu sarana hiburan yang disukai banyak orang, bahkan hampir semua orang menyukainya. Hiburan merupakan suatu hal yang sangat penting dalam suatu kehidupan seseorang. Namun sayangnya, banyak orang yang memiliki waktu yang sangat terbatas sehingga mereka cenderung tidak memiliki waktu untuk pergi ke rental-rental film untuk menyewa film-film terbaru. Namun hal ini tidak akan menjadi masalah ketika suatu perusahaan rental film melakukan suatu promosi ataupun pemasaran melalui media internet. Pelanggan dapat memilih film-film yang akan disewa tanpa harus pergi ke tempat penyewaan film.

Sebagai contoh, seorang pelanggan yang bekerja di suatu kantor, dan memulai pekerjaannya dari pukul 8 pagi hingga 5 sore. Sebelum memulai rutinitas pekerjaannya pelanggan tersebut dapat memesan film melalui website, dan kemudian pihak perusahaan akan melakukan pengantaran film ke alamat pelanggan tersebut, sehingga pada saat pelanggan tersebut tiba di rumah, film sudah dapat dinikmati tanpa harus bepergian untuk menyewa film.

Namun masalah belum selesai sampai tahap tersebut. Masalah lain yang harus dihadapi oleh perusahaan rental film adalah banyaknya pelanggan yang merasa bingung ketika hendak menyewa suatu film, film apakah yang harus disewa? terkadang pemberian review suatu film masih belum cukup membuat peminjam yakin untuk menyewa film tersebut. Untuk membantu meyakinkan peminjam maka dapat digunakan faktor orang ketiga, dimana orang ketiga tersebut adalah orang-orang yang pernah menyewa film-film yang sama dengan film-film yang pernah disewa oleh peminjam tadi, dengan banyaknya kesamaan film yang penah disewa oleh orang ketiga dan peminjam tadi maka dapat dilihat adanya kemungkinan orang ketiga memiliki kesamaan selera dengan peminjam tadi. Dari adanya kemungkinan kesamaan selera tersebut dapat dicari film-film yang akan dijadikan bahan rekomendasi untuk peminjam.

Untuk itulah, maka dibuat suatu website yang dapat menanggulangi masalah tersebut. Website ini akan memberikan kemudahan kepada peminjam, dimana peminjam dapat menyewa film-film tanpa harus menuju ke tempat penyewaan film. Selain itu juga akan diberikan rekomendasi film yang dapat disewa oleh peminjam, dimana film yang direkomendasikan tergantung dari daftar sejarah penyewaan film-film dari peminjam tersebut yang nantinya akan disamakan dengan milik orang lain sebagai orang ketiga, sehingga muncul film-film yang dapat direkomendasikan untuk peminjam. Dengan adanya sistem rekomendasi dapat membantu peminjam dalam memilih film-film yang harus disewa. Pada akhirnya tidak hanya peminjam yang diuntungkan, tetapi juga perusahaan karena omzet penyewaan pasti akan bertambah

\section{LANDASAN TEORI}

Ruang lingkup dalam pembuatan sistem Rekomendasi Collaborative untuk penyewaan DVD dengan menggunakan Item To Item Similiarity Mapping ini adalah sebagai berikut:

Suatu rental DVD ingin meningkatkan pendapatannya dengan cara menyediakan fasilitas memesan film melalui internet yang dapat digunakan oleh para pelanggannya melalui internet. 


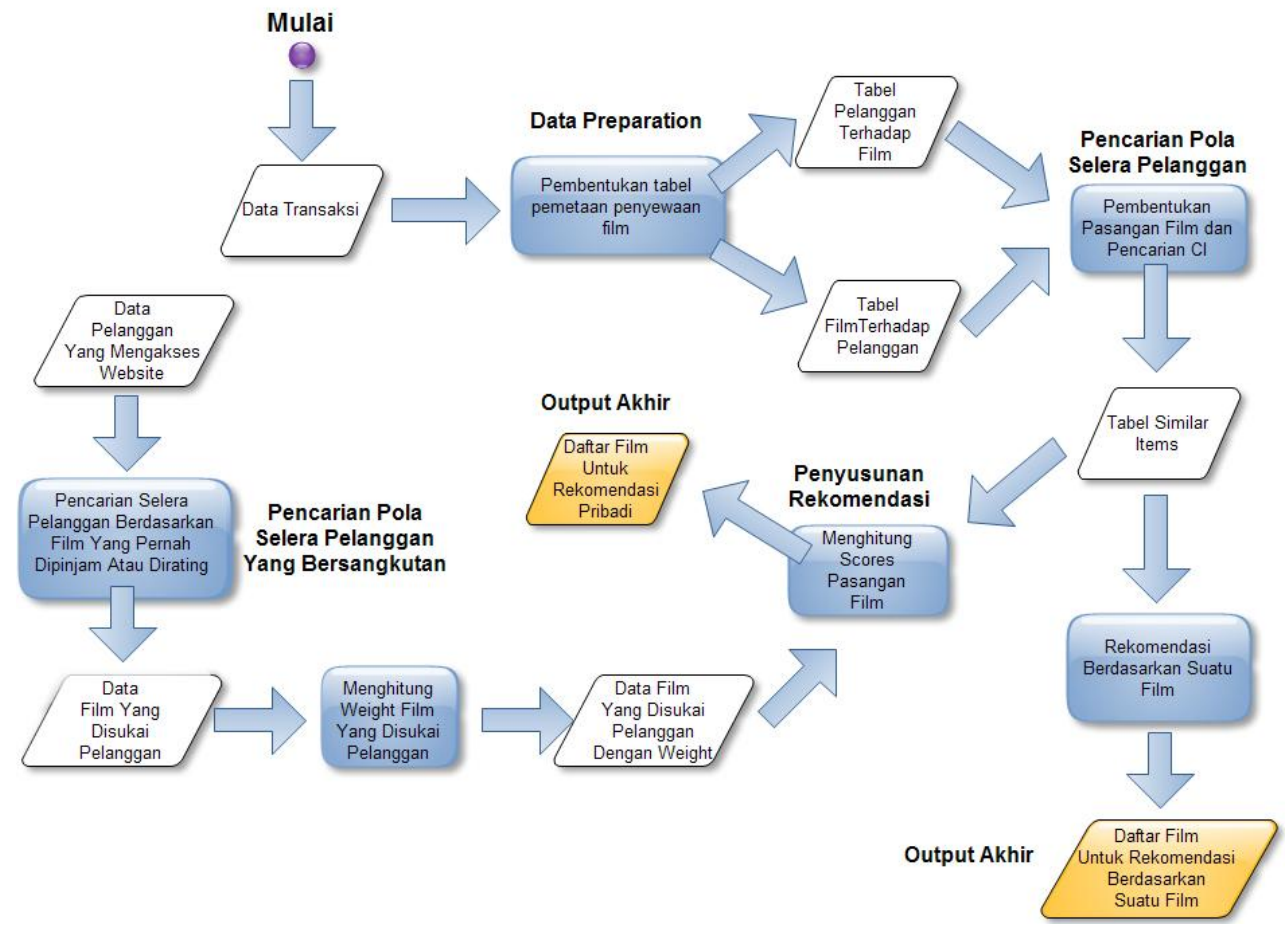

Gambar 1. Gambaran Umum Cara Kerja Collaborative Recommendations Using Item To Item Similarity Mappings

\section{Skenario penyewaan}

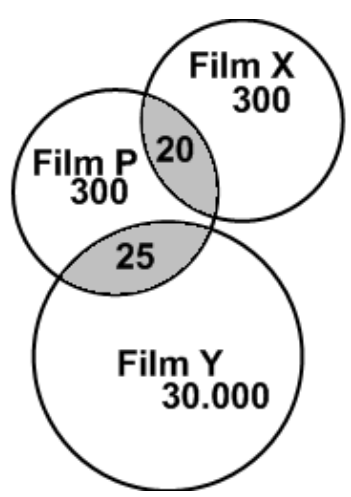

\section{Gambar 2. Contoh transaksi penyewaan film}

. Terdapat suatu katalog yang menampilkan film-film yang dapat disewa dalam situs ini. Setiap pelanggan yang hendak menyewa film harus mempunyai suatu id pada situs ini. Untuk menyewa, ke dalam daftar penyewaan, para pelanggan dapat memilih film-film yang akan disewa dengan melakukan klik kiri pada link film yang bersangkutan, setelah itu memasukkan film tersebut.

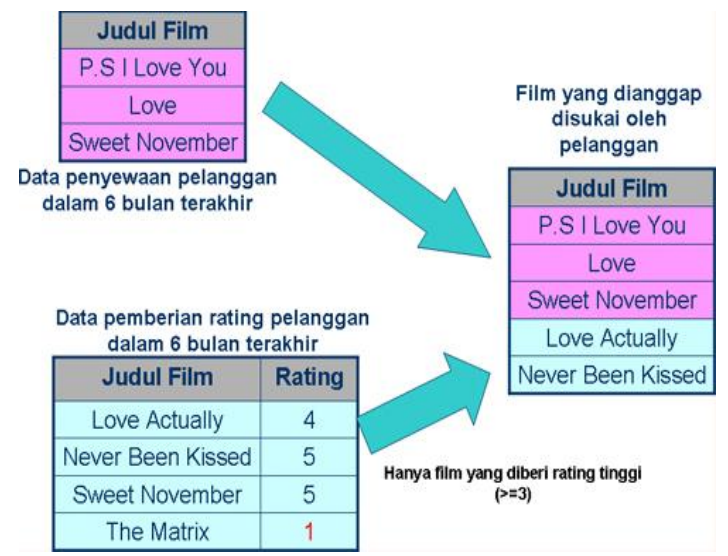

\section{Gambar 3. Contoh pencarian selera film seorang pelanggan}

Setelah selesai memilih, pelanggan dapat melihat daftar penyewaan untuk mengetahui harga yang harus dibayar dan kemudian melakukan pembayaran. Pembayaran dapat dilakukan secara online melalui kartu kredit ataupun ketika film diantarkan ke tempat tujuan pelanggan. Pengantaran dan pengambilan film yang akan dikembalikan dalam setiap harinya terbagi menjadi 3 gelombang, yaitu pukul 09.00, pukul 13.00 dan pukul 17.00. Film yang dipesan akan di- 
antarkan sesuai jam dari suatu gelombang di atas jam pemesanan. Pengambilan dan pengiriman suatu film akan dikenakan biaya tambahan.

\section{Spesifikasi Program}

Berikut ini adalah poin-poin spesifikasi dalam pembuatan sistem Rekomendasi Collaborative untuk penyewaan DVD dengan menggunakan Item To Item Similiarity Mapping : Situs akan dikembangkan dengan menggunakan bahasa pemrograman VB.NET DBMS yang digunakan dalam situs ini adalah SQL Server. Database menggunakan data transaksi asli suatu perusahaan rental DVD di Kediri, yang bernama Star Disc.

\section{Fitur-fitur}

Fitur yang terdapat dalam pembuatan sistem Rekomendasi Collaborative untuk penyewaan DVD dengan menggunakan Item To Item Similiarity Mapping diantaranya; (*) Pada halaman awal akan muncul beberapa film terlaris yang akan ditampilkan bersamaan dengan kata penyambut. Terdapat menu untuk login, pendaftaran, pengaturan, pencarian, dan rekomendasi.

(*) Terdapat dua jenis rekomendasi pada website ini, yang pertama dikenal dengan istilah instant recommendations. Dimana menu rekomendasi digunakan untuk mencari rekomendasi sesuai dengan sejarah penyewaan seorang pelanggan (instant recommendations). Selain itu, pada bagian bawah, juga terdapat nama-nama pelanggan lain yang memiliki sejarah penyewaan yang hampir sama dengan pelanggan yang bersangktuan.

Dari nama-nama pelanggan lain jika dipilih akan menampilkan film-film yang pernah disewa oleh pelanggan tersebut. Dengan adanya daftar film yang pernah disewa oleh pelanggan lain, diharapkan dapat menjadi acuan pelanggan tadi dalam memilih film-film yang akan disewa. Ditampilkan juga secara langsung film terakhir yang disewa oleh pelanggan lain tersebut. Rekomendasi yang berikutnya, merupakan rekomendasi yang diberikan bedasarkan suatu film tertentu. Ketika pelanggan memilih salah satu film, maka akan muncul suatu halaman baru yang menjelaskan informasi tentang film tersebut.

Pada bagian bawah, akan muncul rekomendasi film-film lain yang mempunyai hubungan yang erat dengan film yang dipilih tadi. Erat tidaknya hubungan antar film ditentukan dengan seberapa sering film-film tersebut pernah disewa oleh peminjam yang sama, tanpa mempedulikan waktu penyewaan

Fasilitas shopping cart yang berfungsi layaknya troli untuk berbelanja pada supermarket. pelanggan dapat memilih film-film yang akan disewa, lalu menekan tombol "tambah" ke daftar sewa. Barang yang sudah masuk ke dalam shopping cart dapat dihapus, jika terjadi kekeliruan. Dalam shopping cart, harga akan ditotal secara langsung, sehingga pelanggan dapat langsung mengetahui total uang yang harus dikeluarkan untuk menyewa sejumlah film-film tersebut.

Film-film yang masuk dalam kategori populer. Setiap film yang jumlah penyewaan keluarnya memenuhi suatu nilai tertentu (threshold number) akan dimasukkan kedalam kategori film populer. Film yang termasuk dalam kategori populer akan digunakan sebagai acuan dalam mencari rekomendasi.

Fasilitas 10 film terlaris, dimana berisi daftar film-film yang paling sering disewa oleh pelanggan situs. Fitur ini berguna untuk lebih meyakinkan pelanggan untuk menyewa suatu film.

Fasilitas laporan-laporan yang dapat diakses oleh administrator. Adapun laporan-laporan yang dapat dilihat adalah:

(1) Laporan film; Pada laporan film, dapat melihat daftar film-film yang ada pada perusahaan rental, selain itu dapat dilihat juga status dari film tersebut (disewa atau tersedia). Laporan dapat disaring (filter) berdasarkan data yang tersedia dari suatu film.

(2) Laporan pelanggan; Digunakan untuk melihat daftar dari pelanggan-pelanggan yang telah terdaftar. Pada laporan ini dapat juga dilihat sejarah penyewaan film dari seorang pelang-gan, dan dapat diketahui pula film apa saja yang belum dikembalikan oleh pelanggan yang bersangkutan. Jika pelanggan tersebut masih membawa film yang sudah melebihi batas pengembaliannya, maka akan diberikan warna yang berbeda. Laporan dapat disaring (filter) berdasarkan data yang tersedia dari seorang pelanggan

(3) Laporan transaksi dan pendapatan; Digunakan untuk melihat secara detail mengenai transaksi penyewaan beserta pendapatan yang didapat perusahaan, seperti tanggal penyewaan, tanggal pengembalian, total denda, total pembayaran, pelanggan yang bersangkutan serta judul film yang disewa. Laporan Transaksi dapat disaring (difilter) berdasarkan tanggal penyewaan, tanggal pengembalian, pelanggan, dan film. Untuk transaksi penyewaan film yang belum dikembalikan 
akan diberikan warna yang berbeda (misalnya biru), begitu juga halnya untuk transaksi yang telah melewati batas waktu penyewaan dan belum dikembalikan akan diberikan warna yang berbeda pula sebagai tanda peringatan (misalnya merah).

Terdapat fasilitas laporan - laporan yang dapat diakses oleh pelanggan. Adapun laporan-laporan yang dapar dilihat adalah:

(1) Laporan sejarah penyewaan Seorang pelanggan dapat melihat sejarah penyewaan yang pernah dilakukannya. Laporan dapat difilter berdasarkan tanggal, dan film.

(2) Laporan status film

Seorang pelanggan dapat melihat daftar lengkap film-film yang sedang keluar, dan dapat melihat tanggal kembali dari film tersebut.

Fasilitas trailer untuk beberapa film, sehingga pelanggan dapat menonton cuplikan suatu film yang akan disewanya terlebih dahulu sebelum melakukan pemesanan.

(1)Terdapat fasilitas untuk memberikan rekomendasi dari seorang pelanggan ke pelanggan lainnya.

(2) Pelanggan dapat memberikan rating dan komentar (shout out) terhadap suatu film. Tentu saja rating yang diberikan pelanggan terhadap suatu film nantinya akan mempengaruhi rekomendasi film yang akan disarankan untuk pelanggan tersebut.

(3) Terdapat fasilitas film hari ini, dimana situs akan menampilkan suatu film secara acak dari database. Film akan ditampilkan pada halaman utama, lengkap dengan kategori film, serta ringkasan cerita dari film tersebut. Dengan adanya fasilitas ini, pelanggan dapat mengetahui cerita tentang suatu film yang mungkin sebelumnya belum pernah diketahui oleh pelanggan tersebut, dengan begitu ada suatu kemungkinan tersewanya film yang kurang populer akan meningkat.

\section{Gambaran umum Algoritma Collaborative Recommendations Using Item To Item Similarity Mapping. \\ Pada awalnya algoritma ini akan} membentuk dua buah tabel baru yang nantinya akan berguna dalam proses pencarian rekomendasi. Tabel pertama akan menyimpan data penyewaan seorang pelanggan terhadap film-film yang pernah disewa (table mapping customers to purchased items, lihat tabel 1),
Tabel 1

Mapping Customers to Purchased Items
\begin{tabular}{|c|c|}
\hline Customer & Purchased Item \\
\hline USER_A & ITEM_A,ITEM_C \\
\hline USER_B & ITEM_C,ITEM_D \\
\hline$\ldots \ldots$ & $\ldots \ldots$ \\
\hline$\ldots \ldots$ & $\ldots \ldots$ \\
\hline
\end{tabular}

sedangkan tabel kedua akan menyimpan data film dan pelanggan-pelanggan yang pernah menyewanya (table mapping purchased items to customers, lihat tabel 2).

Tabel 2

Mapping Purchased Items to Customers

\begin{tabular}{|c|c|}
\hline Item & Customers Who Purchased \\
\hline ITEM_A & USER_B, USER_D \\
\hline ITEM_B & USER_A, USER_F \\
\hline$\ldots \ldots$ & $\ldots \ldots$ \\
\hline$\ldots \ldots$ & $\ldots \ldots$ \\
\hline
\end{tabular}

Untuk film-film yang sama yang pernah disewa oleh seorang pelanggan akan dima-sukkan satu saja ke dalam tabel-tabel diatas, misalnya seorang pelanggan pernah menyewa ITEM_A sebanyak 5 kali, maka dalam tabel hanya dicatat satu kali saja.

Setelah itu dilakukan pencarian film yang termasuk kategori populer. Film yang termasuk kategori populer dapat didapatkan dengan melihat jumlah sewa terhadap film tersebut, jumlah sewa harus melewati suatu angka tertentu (threshold number). Setelah mendapatkan film yang berkategori populer, maka akan dicari jumlah dari pasangan penyewaan setiap film populer dengan semua film yang pernah disewa oleh seorang pelanggan yang sama, tanpa mempedulikan waktu penyewaannya.

Langkah berikutnya adalah menghitung CI (commonality index) dari jumlah setiap pasangan film populer dan semua film. Nilai dari CI akan menunjukkan tingkat kemiripan antar dua buah film, bedasarkan penyewaannya. Semakin tinggi nilai CI maka hubungan antar kedua film tersebut semakin erat, begitu juga sebaliknya.

CI dapat dicari dengan cara:

$$
C I(\text { Popular }, \text { Item })=\frac{\text { Customer_of_Popular_and_Item }}{\sqrt{\begin{array}{l}
\text { Customer_of_Popularx } \\
\text { Customer_of_Item }
\end{array}}}
$$


Langkah berikutnya adalah mencari weight dan scores. Weight dicari bedasarkan penyewaan seorang pelanggan yang akan diberi rekomendasi terhadap film-film yang berkategori populer (akan dicari wight untuk setiap barang populer yang pernah disewa oleh pelanggan tersebut), dan mempedulikan waktu penyewaan. Weight dapat dicari dengan cara:

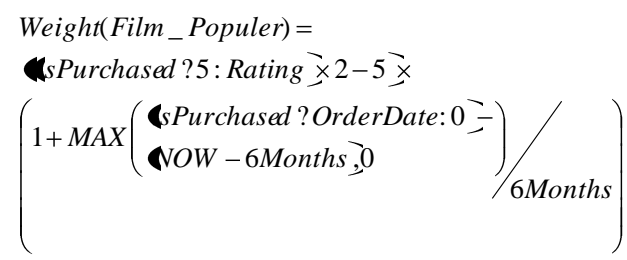

Setelah mendapatkan nilai weight maka nilai weight akan dikalkulasikan dengan nilai CI untuk semua barang yang menjadi pasangan barang populer tersebut. Hasil kalulasi antara nilai CI dan weight dikenal dengan istilah scores.

Setelah memiliki scores untuk masingmasing barang populer dan seluruh film yang menjadi pasangannya, maka score untuk tiaptiap film yang sama akan dijumlahkan dan kemudian diurutkan dari yang paling besar ke kecil. Dari hasil pengurutan tersebut dapat diketahui film mana yang memiliki score tertinggi, dan siap untuk dijadikan bahan rekomendasi.

\section{MODEL, ANALISIS, DESAIN, DAN IMPLEMENTASI}

\section{Model}

Secara khusus mengenani metode collaborative recommendations yang akan digunakan sebagai metode untuk pemberian rekomendasi kepada pelanggan oleh sistem website. Sistem rekomendasi atau yang biasa disebut juga Recommender System digunakan oleh situs-situs e-commerce untuk memberikan suatu rekomendasi produk kepada pelanggan.

Rekomendasi yang diberikan umumnya dilakukan berdasarkan selera pelanggan yang bersangkutan. Untuk mengetahui selera pelanggan yang bersangkutan dapat dilihat dari transaksi transaksi sehari-hari yang dilakukan pelanggan, selain itu jika website memiliki sistem pemberian nilai rating, maka pemberian nilai rating seorang pelanggan terhadap suatu produk dapat digunakan sebagai acuan lain untuk mengetahui selera pelanggan yang bersangkutan.
Pemberian suatu rekomendasi pada website selain diharapkan dapat meningkatkan penjualan perusahaan kepada pelanggan, diharapkan juga akan mampu menambah kenyamanan pelanggan dalam menjelajahi website. Pelanggan tidak akan bingung dalam memilih barang karena sistem akan memberikan rekomendasi kepada pelanggan. Salah satu situs e-commerce yang menggunakan sistem rekomendasi adalah Amazon.com.

Terdapat berbagai macam cara / algoritma yang dapat digunakan dalam pemberian rekomendasi kepada pelanggan. Algoritma yang digunakan dalam pembangunan tugas akhir ini bernama Collaborative Recommendations Using Item to Item Similarity Mappings. Kata "Similarity" pada nama algoritma mengacu pada tabel yang akan dibentuk yang memetakan pasangan pasangan barang yang ada dalam database, beserta nilai kemiripan barang tersebut, misalkan banyak pelanggan yang membeli barang A juga membeli barang $B$ maka nilai kemiripan barang A dan barang B semakin tinggi.

Sistem rekomendasi collaborative atau lebih dikenal dengan istilah collaborative filtering merupakan suatu proses pemberian rekomendasi oleh sistem komputer berdasarkan data yang terdapat pada database. Aplikasi yang menggunakan collaborative filtering biasanya menggunakan data dalam ukuran yang besar. Collaborative filtering sendiri merupakan suatu sistem perekomendasi yang memiliki banyak metode dan yang diimplementasikan dalam tugas akhir ini adalah Collaborative Recommendations Using Item To Item Similarity Mappings.

Pemodelan Collaborative Recommendations Using Item To Item Similarity Mappings dikembangkan oleh Gregory D. Linden, Jennifer A. Jacobi, Eric A. Benson. Ketiganya berasal dari Seattle, Amerika. Al-goritma tersebut merupakan metode pem-berian rekomendasi yang digunakan oleh Amazon.com. Algoritma ini di patenkan oleh Amerika, dengan nomor paten US 6,266,649 B1, pada tanggal 24 Juli 2001.

\section{Analisa}

Pada bagian analisa akan membahas deskripsi kerja sistem secara detail, seperti hal-hal yang harus dilakukan seorang calon pelanggan yang belum terdaftar pada website hingga menjadi anggota website, dapat melakukan transaksi penyewaan film serta mendapatkan rekomendasi. Selain itu pada bagian 
definisi dan spesifikasi kebutuhan akan dijelaskan mengenai hal-hal yang dibutuhkan oleh website sehingga sistem kerja website dapat menjadi maksimal, dan akan dijelaskan fitur-fitur yang disediakan website untuk dapat menangani kebutuhan kebutuhan tersebut. Subbab Data flow diagram, dimulai dari Context diagaram, Data flow diagram level 0 dan Data flow diagram level 1 akan menjelaskan arus data yang mengalir sebagai input dan output dari proses-proses yang membangun sistem penyewaan DVD online, Context diagram dan Data flow diagram level 0 dibedakan dalam pembuatan analisa sistem penyewaan DVD online ini.

Selain menjelaskan mengenai ana-lisa sistem, pada bab ini akan dijelaskan mengenai desain sistem. Desain arsitektural akan menjelaskan fitur-fitur yang membangun sistem sehingga menjadi satu kesatuan sistem penyewaan DVD online. Data data yang diperlukan selama sistem berjalan akan tersimpan dalam suatu database yang memiliki tabel-tabel untuk menyimpan data data tersebut sesuai dengan fungsinya masing masing. Struktur tabel tabel pada database, serta hubungan antar tabel akan dibahas pada subbab desain database. Pada subbab berikutnya akan dibahas mengenai desain interface, yang akan menampilkan halaman halaman website yang ada, beserta penjelasan tentang fungsi fungsi atau fitur yang ada pada halaman tersebut. Desain terakhir yang akan dibahas adalah desain prosedural. Desain prosedural akan menggambarkan langkah-langkah interaksi yang terjadi antara pelanggan website dan sistem yang bekerja, ketika pelanggan website menggunakan fasilitas fasilitas yang ada pada website

\section{Desain}

Pada subbab ini akan dijelaskan mengenai sistem pada website penyewaan DVD online. Website ini merupakan suatu website yang menyediakan layanan jasa, dimana pelanggan dapat menyewa film melalui media internet. Film yang telah disewa oleh pelanggan akan diantarkan ke alamat pelanggan, dimana alamat pelanggan sudah tercatat dalam data perusahaan ketika pelanggan melakukan pendaftaran sebagai anggota.

Untuk menyewa film, pelanggan harus terdaftar sebagai anggota terlebih dulu. Jika seorang pelanggan belum memiliki keanggotaan pada website, maka pelanggan dapat melakukan pendaftaran secara gratis pada website dengan memilih halaman yang telah disediakan. Setelah calon anggota resmi terdaftar sebagai pelanggan, maka penyewaan film dapat dilakukan.

Terdapat suatu katalog yang menampilkan berbagai macam film yang tersedia pada website ini. Untuk melakukan pencarian film pada katalog film yang telah disediakan, pelanggan dapat menggunakan fasilitas pencarian film, dimana untuk menggunakan fasilitas tersebut, pelanggan dapat menggunakan tiga buah cara yang berbeda-beda yaitu pencarian film berdasarkan huruf depan suatu film, pencarian film berdasarkan judul suatu film dan pencarian film secara detail. Berikutnya setelah menemukan film yang sudah ditentukan, Pelanggan dapat melihat detail suatu film dengan memilih film yang diinginkan.

Selain itu, untuk membantu para pelanggan dalam menentukan film-film yang akan disewa, website akan memberikan beberapa layanan rekomendasi sehingga pelanggan mendapat bantuan dalam menentukan film-film yang akan disewa. Ketika seorang pelanggan melihat detail dari suatu film, maka website akan memberikan daftar film-film lainnya yang biasanya disewa oleh pelanggan lain yang juga menyewa film yang dilihat oleh pelanggan yang bersangkutan. Selain itu terdapat fasilitas rekomendasi pribadi, dimana fasilitas ini akan mencari informasi mengenai selera pelanggan yang akan diberikan rekomendasi. Setelah mengetahui selera pelanggan yang bersangkutan maka website akan memberikan rekomendasi berupa sekumpulan film yang belum pernah disewa maupun dirating oleh pelanggan tersebut. Perlu diperhatikan untuk dapat menggunakan fasilitas rekomendasi pribadi seorang pelanggan wajib melakukan peni-laian atau penyewaan terhadap beberapa film terlebih dahulu, agar website dapat mengetahui selera dari pelanggan tersebut. Rekomendasi juga dapat diberikan antar satu pelanggan ke pelanggan lainnya.

Untuk menyewa suatu film, pelanggan dapat memilih tombol yang bertuliskan "Masukkan ke daftar pinjaman", untuk memasukkan film tadi ke dalam daftar pinjaman miliknya. Setelah selesai memilih film, pelanggan dapat masuk ke menu daftar pinjaman untuk melihat total yang harus dibayar, serta melihat tanggal pengembalian film-film tersebut. 
Proses penyewaan film dapat dilihat pada gambar:

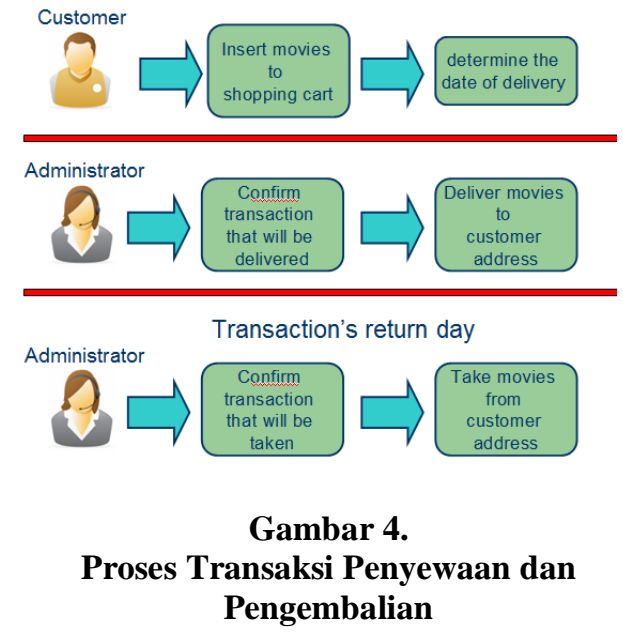

Pelanggan tidak diperbolehkan menyewa lebih dari satu film yang sama pada suatu transaksi penyewaan. Kemudian untuk melakukan pembayaran pelanggan dapat memilih tipe pembayaran, dilakukan secara online atau dilakukan ketika barang dian-tarkan ke alamat pelanggan yang bersangkutan, tipe pembayaran yang kedua hanya dapat dilakukan oleh pelanggan yang sudah dianggap terpercaya oleh perusahaan.

Langkah berikutnya dilakukan oleh administrator. Administrator akan melakukan kornfirmasi mengenai pengantaran film sesuai jadwal yang telah ditentukan oleh pelanggan. Setelah melakukan konfirmasi terhadap transaksi transaksi penyewaan yang akan diantar, film film akan diantarkan ke alamat pelanggan yang sesuai. Langkah terakhir, ketika hari pengembalian transaksi tiba, administrator akan melakukan konfirmasi untuk transaksi transaksi yang akan diambil, dan setelah itu film akan diambil dari alamat pelanggan yang sesuai.

Untuk proses pengantaran dan pengambilan film, setiap harinya dilakukan melalui tiga gelombang. Yaitu pukul 09.00, 13.00 dan 17.00. Jika pelanggan melakukan penyewaan pada malam hari, misalnya pukul 19.00 maka pengantaran film akan dilakukan besok hari pada pukul 09.00. Jam pengantaran akan ditutup 15 menit sebelum waktu jam pengantaran dimulai, misalkan gelombang 09.00, akan ditutup pada pukul 08.45. Untuk pengembalian film, perusahaan akan mengambil film sesuai dengan batas waktu yang telah diberikan. Pengambilan film tidak dikenakan biaya tambahan selama film tersebut kembali tepat waktu. Film yang disewa oleh pelanggan dapat dikembalikan satu per satu, misalkan seorang pelanggan menyewa 5 film, pengembalian dapat dilakukan secara bertahap, dua film pada hari senin, tiga film lainnya pada hari selasa. Jika film tidak kembali pada batas waktu yang telah ditentukan maka akan dikenakan sanksi berupa denda. Perhitungan denda per harinya dilakukan dengan cara menjumlahkan harga sewa tiap film yang terkenda denda dan biaya kirim.

\section{Implementasi}

Pada proses implementasi, akan dijelaskan pula mengenai implementasi pembentukan tabel similar items. Penjelasan implementasi mengenai pembentukan tabel similar items akan berbeda dengan penjelasan implementasi lainnya, hal ini disebabkan karena pembentukan tabel similar items tidak dilakukan melalui ASP.NET melainkan menggunakan salah satu fasilitas SQL Server yang umumnya digunakan untuk melakukan transformasi data, yaitu DTS (Data transformation services). Karena pembentukan tabel similar items dilakukan dengan penjadwalan dan memerlukan waktu yang lama, maka DTS merupakan tools yang cocok digunakan untuk proses tersebut. Pada DTS pemakai dapat menentukan penjadwalan kerja suatu proses, dilakukan berdasarkan hari, minggu atau bulan. Selain itu pemakai juga dapat menjadwalkan jam dimana proses akan berjalan dengan sendirinya.

Tabel similar items (pada implementasinya di database bernama (RekomendasiSimilarItems) akan menyimpan data pemetaan antar dua film serta nilai kesamaan pasangan film tersebut. Nilai kesamaan antar film tersebut dikenal dengan istilah CI (commonality index).

Pembentukan tabel similar items dilakukan dengan menggunakan ETL tool yang disediakan oleh SQL Server yang dikenal dengan nama Data Transformation Services. Hal ini dilakukan karena pembentukan tabel similar items dilakukan berdasarkan penjadwalan, misalkan 1 minggu, 1 bulan atau 6 bulan sekali, dan DTS menyediakan fasilitas untuk melakukan penjadwalan tersebut. Jadi, nantinya proses DTS untuk membentuk tabel similar items akan berjalan sendirinya sesuai jadwal yang ditentukan. Untuk lebih jelas mengenai proses kerja DTS lihat Gambar 5. Pembentukan tabel similar items list dapat dibedakan menjadi 2 proses, seperti yang tertulis pada gambar 2.2, yaitu proses 1 dan proses 2 . 


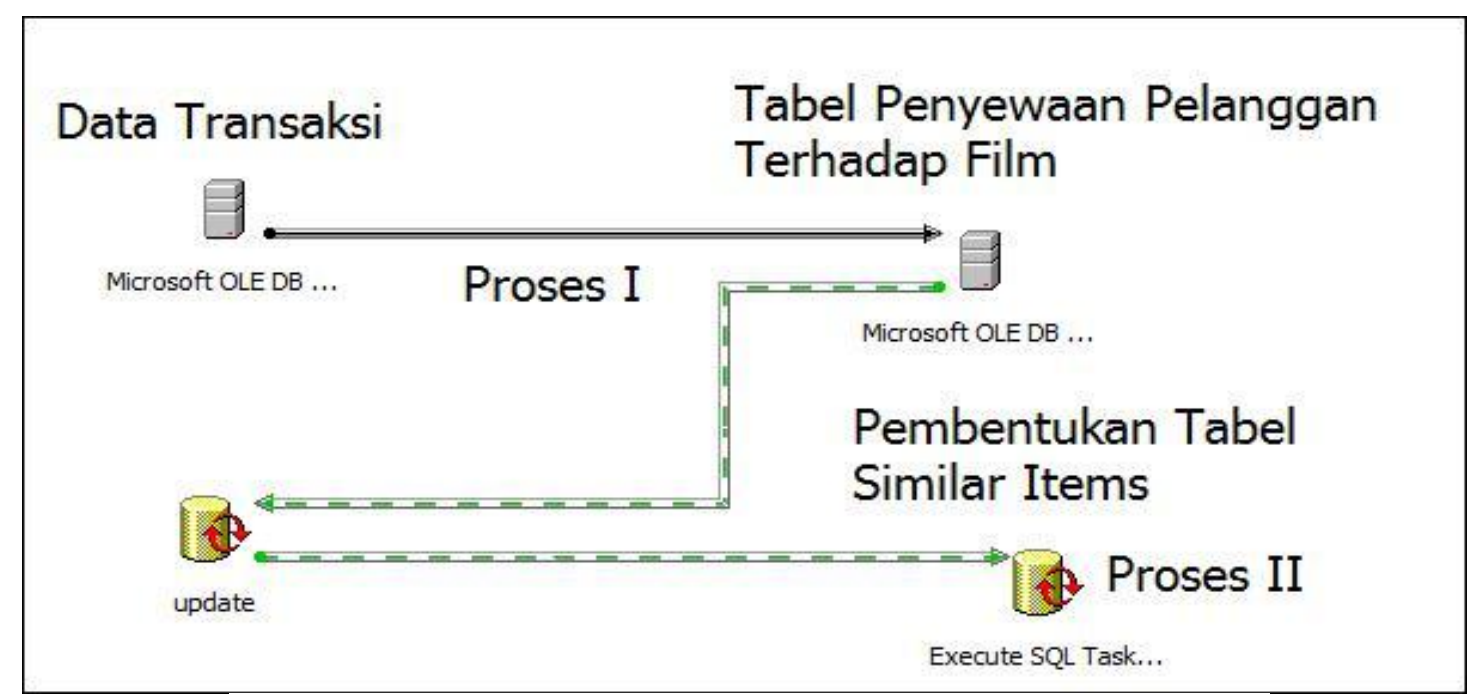

Gambar 5.

Proses Kerja Pembentukan Similar Items Pada DTS

Proses 1 akan membentuk tabel penyewaan pelanggan terhadap film. Tabel ini akan mencatat semua data pelanggan yang pernah meminjam film beserta film-film yang pernah disewa oleh pelanggan tersebut. Sedangkan proses 2 akan membentuk tabel similar items, yang data inputnya didapatkan dari tabel penyewaan pelanggan terhadap film yang dibentuk pada proses 1 .

Pada proses 1, akan diambil data transaksi penyewaan film yang terjadi di perusahaan. Perintah query akan dijalankan untuk menyaring data-data transaksi tersebut. Implementasi penyaringan data transaksi perusahaan data dilihat pada segmen program d.1.

\section{Segmen Program d.1 Proses Penyaringan Data Transaksi \\ 1 : SELECT h.indexpelanggan, d.indexfilm \\ 2: FROM tdsewa d INNER JOIN \\ 3: thsewa $\mathrm{h}$ ON d.indexsewa $=$ h.indexsewa \\ 4: WHERE h.prosesdts $=0$ \\ GROUP BY h.indexpelanggan, d.indexfilm}

Segmen program diatas digunakan untuk mencari data semua pelanggan dan data film yang pernah dipinjam pelanggan tersebut. Perintah GROUP BY pada baris 5 digunakan untuk mengambil satu data saja ketika terjadi situasi dimana pelanggan pernah meminjam film yang sama lebih dari satu kali. Misalkan pelanggan yang sama pernah meminjam film P.S I Love You sebanyak 7 kali, maka dengan menggunakan perintah tersebut data pelanggan meminjam film P.S I Love You hanya terpilih sebanyak satu kali saja, hal itu juga berlaku untuk semua penyewaan pelanggan terhadap film yang sama, walaupun peminjaman terhadap film yang sama berjumlah 100 kali atau bahkan 1000 kali.

Langkah berikutnya adalah melakukan proses transformasi data dari tabel transaksi yang sudah disaring dengan menggunakan perintah SQL yang tertulis pada segmen program ke tabel penyewaan film terhadap pelanggan, seperti yang terlihat pada Gambar 2.3. Setelah menjalankan proses tersebut akan dijalankan proses update seperti yang terlihat pada gambar 2.2. Proses update digunakan untuk menandakan transaksi pe-nyewaan yang sudah masuk ke dalam tabel penyewaan pelanggan terhadap film, hal ini dilakukan agar ketika proses DTS berikutnya dijalankan transaksi yang sama tidak perlu diproses lagi.

Setelah menjalankan perintah update, proses berikutnya adalah menjalankan proses ke 2 pada DTS, yaitu membentuk tabel similar items. Proses pembentukan tabel similar items pada database, akan menjalankan perintah EXEC generate-SimilarItems ?,? , dimana perintah tersebut akan menjalankan prosedure generateSimi-larItems yang ada pada database dengan menggunakan dua buah parameter, parameter pertama digunakan untuk menentukan jumlah minimal suatu film tersewa agar film tersebut masuk ke dalam predikat film populer, bernilai 70, dan patameter kedua merupakan nilai yang digunakan untuk menentukan jumlah minimal suatu film tersewa agar film tersebut digunakan dalam tabel similar items, bernilai 10 . 


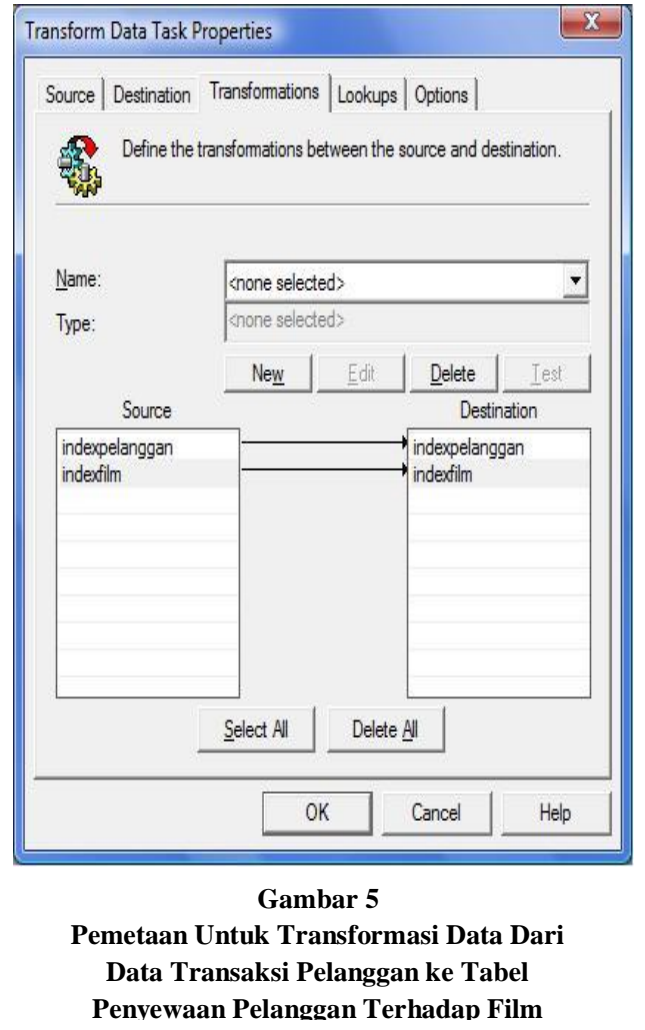

Dengan kata lain tabel similar items akan memasangakan film film yang termasuk kategori populer, dimana film harus tersewa lebih dari atau sama dengan 70 pelanggan, dengan film film lain yang harus tersewa lebih dari atau sama dengan 10 pelanggan. Nilai kedua parameter tersebut ditentukan melalui menu variable global pada DTS. Implementasi dari prosedure generateSimilarItems dapat dilihat pada segmen program d.2.

Perhatikan segmen program d.2. Baris 2 dan 3 akan mengambil nilai parameter pertama dan kedua. Baris 6 akan melakukan perubahan pada data film dengan memberikan predikat pada film populer yang memiliki jumlah pelanggan yang mencapai 70 (sesuai dengan parameter 1 yang tersimpan di variabel @ paramPopular-Threshold), jumlah pelanggan tersebut dihitung berdasarkan tabel penampung sementara yang baru dibentuk pada proses DTS yang pertama. Baris 7 akan mengambil semua data dari semua film populer yang ada, kemudian baris 10 akan melakukan perulangan untuk setiap film populer yang ada. Baris 12 akan mengambil semua data dari semua film yang ada, yang memiliki jumlah pelanggan yang pernah meminjamnya diatas 10 , kemudian baris 15 akan melakukan perulangan untuk setiap film populer yang ada. Pada baris 10 perintah SQL indexfilm $<>$ @indexFilmPopuler digunakan agar tidak terjadi pasangan film populer dengan film lainnya yang sama dengan film populer tersebut.

Baris 18 akan mengambil nilai dari database, jika pasangan yang akan dibentuk maka akan mengembalikan nilai 1, jika belum ada maka akan mengembalikan nilai 0 , nilai tersebut disimpan pada variabel @pasanganSudahAda, pada baris 19 dilakukan pemeriksaan apakah pasangan yang akan dibentuk sudah terdaftar pada tabel similar items (pasangan film A dan film B, dianggap sama dengan pasangan film $B$ dan film $A$, jadi hanya pasangan film A dan film $B$ yang akan tersimpan). Jika belum maka pasangan film akan dimasukkan kedalam tabel similar items.

Baris 21 digunakan untuk mengisi variabel @getCountItem1And2, dengan jumlah pelanggan yang menyewa film populer dan pasangannya yang akan dibentuk. Baris 27 dan baris 28 digunakan untuk mencari jumlah pelanggan yang menyewa masing-masing film yang akan dipasangkan, jumlah pelanggan yang pernah menyewa film dicari berdasarkan tabel penampung sementara yang dibentuk pada proses 1 . Baris 30 digunakan untuk memasukkan data pasangan film beserta nilai CI ke dalam tabel similar items, nilai CI dapat dicari dengan menggunakan jumlah pelanggan yang meminjam pasangan film dan masing masing film dari pasangan tersebut. Untuk dapat lebih memahami mengenai pembentukan tabel similar items yang memetakan pasangan pasangan film beserta menyimpan nilai kemiripan (CI) tiap pasangan film, dapat melihat algoritma yang telah dibahas.

\section{SKENARIO UJICOBA}

Mengenai uji coba untuk website yang dibuat dan uji coba dari hasil rekomendasi yang dihasilkan oleh sistem. Uji coba terhadap website, akan dilakukan terhadap fiturfitur yang terdapat pada website. Fitur yang diuji cobakan, beserta hasil dari uji coba akan dituliskan dalam bentuk tabel.

Untuk ujicoba hasil rekomendasi, hasil rekomendasi tersebut akan dibandingkan dengan hasil jawaban beberapa orang yang menjadi sukarelawan. Dari perbandingan tersebut akan dihitung tingkat keakuratan dari rekomendasi yang diberikan oleh sistem rekomendasi website. Untuk ujicoba hasil rekomendasi, hasil rekomendasi tersebut akan dibandingkan dengan hasil jawaban beberapa orang yang telah mencoba dengan menjadi sukarelawan. 


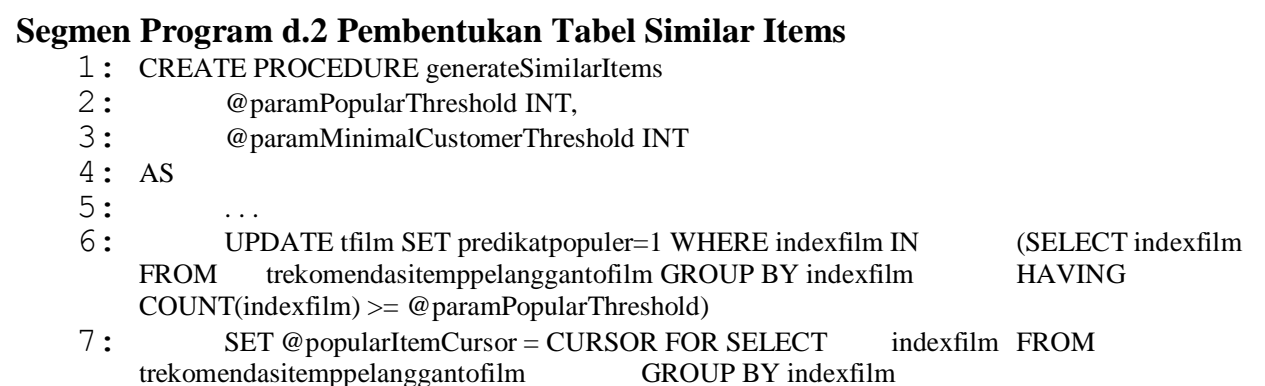

9. $\quad$ FETCH

9: $\quad$ FETCH NEXT FROM @ popular

11: BEGIN

$12:$

@LE@FETCH_STATUS = 0

i. HAVING COUNT(indexfilm) >= @ paramPopularThreshold ORDER BY indexfilm

GROUP BY

SET @ otherItemCursor = CURSOR FOR SELECT indexfilm FROM

trekomendasitemppelanggantofilm WHERE indexfilm $<>@$ indexFilmPopule

indexfilm HAVING COUNT(indexfilm) $>=$ @ paramMinimalCustomerThreshold

ORDER BY indexfilm

OPEN@otherItemCursor

$14:$

FETCH NEXT FROM @ otherItemCursor INTO@ @ indexFilmOther

WHILE@@FETCH_STATUS = 0

BEGIN

16 :

SET @ pasanganSudahAda=0

SELECT @ pasanganSudahAda $=$ COUNT(indexfilm1)

FROM trekomendasisimilaritems WHERE

1. (indexfilm1=@indexFilmPopuler AND

indexfilm2=@indexFilmOther) OR

(indexfilm2=@indexFilmPopuler AND

indexfilm1=@indexFilmOther)

19

$20:$

IF @ pasanganSudahAda $=0$

BEGIN

21:

WHERE

SET @ getCountItem1 And2=CURSOR FOR SELECT

COUNT(indexpelanggan) FROM trekomendasitemppelanggantofilm

(indexfilm = @ indexFilmPopuler) OR (indexfilm = @indexFilmOther) GROUP BY indexpelanggan HAVING

COUNT (indexpelanggan) $=2$

$22:$

$23:$

OPEN@ @etCountItem1And2

SET @ countItem1And2=@@CURSOR_ROWS

CLOSE @ getCountItem1And2

IF @ countItem1And2 >3

BEGIN

$26:$

$27:$

28:

SELECT @ countitem1 =

COUNT(indexfilm) FROM trekomendasitemppelanggantofilm WHERE indexfilm=@indexFilmPopuler GROUP BY indexfilm

$$
\text { 29: @countItem2) }
$$

$$
30:
$$

$31:$

$32:$

$33:$

$34:$

$35:$

$36:$

$37:$

SELECT @ countitem $2=$ COUNT(indexfilm) FROM trekomendasitemppelanggantofilm WHERE indexfilm=@indexFilmOther GROUP BY

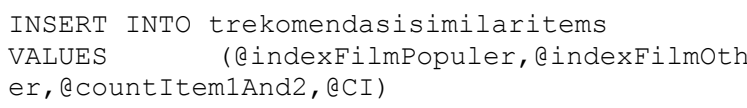

aindexFilmother 
Dari perbandingan tersebut akan dihitung tingkat keakuratan dari rekomen-dasi yang diberikan oleh sistem rekomendasi website. Uji coba akan dilakukan sebanyak dua kali, uji coba pertama akan mengukur tingkat keakuratan dari hasil rekomendasi berdasarkan suatu film, sedangkan uji coba ke dua akan mengukur tingkat keakuratan hasil rekomendasi pribadi seorang pelanggan.

Rekomendasi yang diberikan oleh sistem rekomendasi website didasarkan atas pemetaan selera selera pelanggan terhadap film film yang ada pada website. Data-data film dan transaksi yang digunakan menggunakan database suatu perusahaan rental film bernama Star Disc, yang beralamat di jalan Dhoho 118 Kediri, Jawa Timur. Data transaksi yang digunakan merupakan transaksi transaksi penyewaan film yang terjadi pada perusahaan tersebut, yang dimulai pada tanggal 23/3/2005 sampai dengan 31/07/2008, dengan jumlah transaksi sebanyak 61.710, dengan jumlah film yang pernah tersewa keluar sebanyak 216.292. Jumlah pelanggan pada database tercatat sebanyak 5582 pelanggan, dan jumlah film terdaftar sebanyak 5395 film. Hasil uji coba yang ditanyakan ke sukarelawan akan dibandingkan dengan hasil rekomendasi yang mengacu kepada database diatas.

Uji coba dilakukan melalui tanya jawab kepada sukarelawan. Kemudian hasil jawaban dari sukarelawan akan dimasukkan ke dalam website, dan kemudian akan dilihat hasil rekomendasi dari website dengan input yang sesuai dengan jawaban sukarelawan tadi. Setelah mengetahui hasil rekomendasi, hasil rekomendasi website tersebut akan kembali dipertanyakan kepada sukarelawan, berikutnya hasil jawaban yang diterima dari sukarelawan dapat dijadikan acuan mengenai besar persentase keakuratan dari rekomendasi yang diberikan kepada pelanggan.

Uji Coba Fitur Website; Untuk Uji coba akan dibahas mengenai uji coba untuk website yang dibuat. Uji coba akan dilakukan terhadap fitur-fitur yang terdapat pada website. Fitur yang diuji cobakan, beserta hasil dari uji coba akan dituliskan pada Tabel 3.

Uji Coba Rekomendasi; Berdasarkan Film Untuk uji coba terhadap hasil rekomendasi film, awalnya sukarelawan akan diberi pertanyaan film apakah yang disukai dan pernah ditonton oleh sukarelawan tersebut. Kemudian akan dicari rekomendasi berdasarkan film yang disukai sukarelawan tesebut, dan sistem rekomendasi akan memberikan 10 film dengan rekomendasi berbunyi "pelanggan yang meminjam film ini biasanya meminjam", dimana kata "film ini" mengacu pada film yang disukai dan pernah ditonton oleh sukarelawan tadi. Dari 10 film yang dihasilkan oleh sistem rekomendasi akan ditanyakan kembali kepada sukarelawan, apakah sukarelawan tesebut juga pernah menonton film yang dijadikan bahan rekomendasi. Kolom hasil rekomendasi berdasarkan film menampilkan 10 film yang menjadi rekomendasi berdasarkan film yang dijadikan acuan, sedangkan kolom "pernah ditonton" berisi data dari sukarelawan yang menyukai dan pernah menonton film, apakah sukarelawan tersebut pernah menonton film hasil rekomendasi sistem. Film yang akan dijadikan acuan pada uji coba ini adalah 50 First Date, yang merupakan salah satu film populer yang ada pada database website.

Dari 5 data yang ditanya kepada para sukarelawan yang pernah menonton film 50 First Date, terdapat 3 sukarelawan yang menyukai 50 First Date, dan 2 yang lain tidak menyukai film 50 First Date, datadata tersebut bisa dilihat pada Lampiran A. Sukarelawan yang pernah menonton dan menyukai 50 First Date juga menonton sebagian besar dari film yang menjadi rekomendasi berdasarkan film 50 First Date, persentase yang tercatat masing masing adalah $70 \%, 80 \%$, dan $70 \%$. Sedangkan untuk 2 sukarelawan yang sudah menonton 50 First Date, dan tidak menyukainya, juga menonton beberapa film yang menjadi rekomendasi dari film 50 First Date, masing masing memiliki persentase sebanyak $40 \%$ dan $30 \%$. Dengan kata lain rata rata untuk sukarelawan yang menyukai film 50 First Date dan juga menonton film yang mirip dengan 50 First Date adalah 75\%, sedangkan persentase untuk sukarelawan yang tidak menyukai film 50 First Date sebesar 35\%.

Uji Coba Rekomendasi Pribadi

Untuk uji coba terhadap hasil rekomendasi pribadi, awalnya sukarelawan akan memberikan penilaian rating tinggi (diatas atau sama dengan 3) untuk film film yang disukai oleh sukarelawan tersebut. Setelah itu film sistem akan memberikan rekomendasi pribadi berupa 20 buah film sesuai dengan selera dari sukarelawan tersebut, dilihat dari penilaian rating sukarelawan. Dari 20 film hasil rekomendasi tersebut kemudian akan diberikan kembali 
kepada sukarelawan tadi, dan sukarelawan akan memberi penilaian suka, tidak atau belum ditonton kepada masing masing film. Jika terdapat film dari hasil rekomendasi yang belum pernah ditonton oleh sukarelawan, maka film tersebut tidak akan di ikutsertakan ke dalam perhitungan, dengan kata lain film yang diikut sertakan dalam perhitungan persentase jumlah fim hasil rekomendasi yang disukai sukarelawan hanyalah film hasil rekomendasi yang pernah ditonton oleh sukarelawan.

Terdapat 3 sukarelawan yang memberikan nilai rating untuk beberapa film yang disukai oleh masing masing sukarelawan, data tersebut bisa dilihat pada Lampiran B. Persentase film yang disukai untuk tiap tiap sukarelawan dihitung dengan cara membagi jumlah film dari hasil rekomendasi pribadi yang disukai dengan jumlah film hasil rekomendasi pribadi yang sudah ditonton, sehingga persentase untuk masing masing sukarelawan adalah $84.2 \%$, $76.9 \%, 76.4 \%$. Nilai rata rata yang didapatkan adalah $79.1 \%$.

\section{HASIL UJICOBA}

Uji coba akan dilakukan sebanyak dua kali, uji coba pertama akan mengukur tingkat keakuratan dari hasil rekomendasi berdasarkan suatu film, sedangkan uji coba ke dua akan mengukur tingkat keakuratan hasil rekomendasi pribadi seorang pelanggan.

Rekomendasi yang diberikan oleh sistem rekomendasi website didasarkan atas pemetaan selera selera pelanggan terhadap film film yang ada pada website. Data-data film dan transaksi yang digunakan menggunakan database suatu perusahaan rental film bernama Star Disc, yang beralamat di jalan Dhoho 118 Kediri, Jawa Timur. Data transaksi yang digunakan merupakan transaksi transaksi penyewaan film yang terjadi pada perusahaan tersebut, yang dimulai pada tanggal 23/3/2005 sampai dengan 31/07/2008, dengan jumlah transaksi sebanyak 61.710, dengan jumlah film yang pernah tersewa keluar sebanyak 216.292. Jumlah pelanggan pada database tercatat sebanyak 5582 pelanggan, dan jumlah film terdaftar sebanyak 5395 film. Hasil uji coba yang ditanyakan ke sukarelawan akan dibandingkan dengan hasil rekomendasi yang mengacu kepada database diatas.

\begin{tabular}{|l|l|}
\hline $\begin{array}{c}\text { Judul Film yang Di } \\
\text { Sukai }\end{array}$ & \multicolumn{1}{|c|}{$\begin{array}{c}\text { Nilai } \\
\text { Rating }\end{array}$} \\
\hline 300 & 4 \\
\hline Transformers & 4 \\
\hline $\begin{array}{l}\text { Pirates Of } \\
\text { Caribbean 3 }\end{array}$ & 5 \\
\hline Superman Returns & 5 \\
\hline Spiderman 3 & 4 \\
\hline Ghost Rider & 3 \\
\hline Shooter & 5 \\
\hline Taxi 4 & 3 \\
\hline
\end{tabular}

\begin{tabular}{|c|c|}
\hline $\begin{array}{c}\text { Hasil Rekomendasi } \\
\text { Pribadi }\end{array}$ & Disukai \\
\hline Die Hard 4.0 & Suka \\
\hline Pathfinder & Tidak \\
\hline Next & Suka \\
\hline Apocalypto & Suka \\
\hline $\mathrm{DOA}$ & Suka \\
\hline Rogue & Suka \\
\hline Harry Potter 5 & Suka \\
\hline Bourne Ultimatum & Suka \\
\hline Rush Hour 3 & Suka \\
\hline Crank & $\begin{array}{l}\text { Belum } \\
\text { ditonton }\end{array}$ \\
\hline $\begin{array}{lll}\text { Night At } & \text { The } \\
\text { Museum } & & \end{array}$ & Suka \\
\hline Warlords & Suka \\
\hline Casino Royale & Suka \\
\hline
\end{tabular}




\begin{tabular}{|c|c|}
\hline TMNT & Tidak \\
\hline Mr. Bean Holiday & Tidak \\
\hline X-Men 3 & Suka \\
\hline $\begin{array}{l}\text { Pirates Of Caribbean } \\
\text { "Dead Man's Crest" }\end{array}$ & Suka \\
\hline $\begin{array}{ll}\text { Resident } & \text { Evil } \\
\text { Extinction } & \end{array}$ & Suka \\
\hline $\begin{array}{l}\text { Fast And } \quad \text { The } \\
\text { Furious, The "Tokyo } \\
\text { Drift" }\end{array}$ & Suka \\
\hline M I : III & Suka \\
\hline \multicolumn{2}{|c|}{$\begin{array}{l}\text { Total Film Disukai : } 16 \\
\text { Total Film Tidak Disukai : } 3 \\
\text { Total Film Belum Ditonton : } 1\end{array}$} \\
\hline
\end{tabular}

Rata Rata Hasil Rekomendasi yang Disukai Oleh Sukarelawan: $16 / 19 * 100 \%=84.2 \%$

\section{SIMPULAN}

Diberikan beberapa kesimpulan mengenai pengembangan yang telah dibuat. Kesimpulan-kesimpulan yang diambil dari pembahasan bab-bab yang telah dibuat antara lain: (1) Hasil uji coba menunjukan tingkat keakuratan rekomendasi pribadi cukup tinggi. Tingkat keakuratan yang didapatkan dengan menggunakan 3 sukarelawan adalah $79.1 \%$ (2) Untuk uji coba rekomendasi berdasarkan suatu film, tingkat persentase untuk sukarelawan yang menyukai film yang dijadikan acuan dalam memberikan rekomendasi dan juga menyukai film film hasil rekomendasi, cukup tinggi, yaitu sebesar $75 \%$, sedangkan untuk pelanggan yang tidak menyukai memiliki tingkat akurasi sebesar 35\%. Dengan melihat data tersebut, maka bisa dikatakan bahwa rekomendasi berdasarkan film yang berbunyi "pelanggan yang biasanya meminjam film ini biasanya meminjam", berjalan dengan baik. (3) Hasil rekomendasi sangat bergantung pada database transaksi yang terjadi di perusahaan. Jadi faktor lingkungan setempat, seperti adat dan selera selera pelanggan di lingkungan tersebut akan mempengaruhi rekomendasi yang dihasilkan, dan tentu saja hasil akan berbeda dengan hasil rekomendasi diperusahaan lain, walaupun algoritma rekomendasi yang digunakan sama persis. (4) Untuk memberikan suatu rekomendasi pribadi kepada seorang pelanggan, pelanggan tersebut harus melakukan transaksi atau setidaknya melakukan pemberian rating yang tinggi terhadap beberapa film. Hal ini dilakukan agar sistem dapat mengetahui selera pelanggan untuk melakukan proses penyusunan rekomendasi pribadi (5) Suatu film harus disewa beberapa kali terlebih dahulu dengan beberapa pelanggan yang berbeda, agar dapat diketahui nilai kemiripan film tersebut dengan film lain yang terdaftar pada database. Nilai kemiripan film tersebut dengan film lain nantinya akan mempengaruhi hasil rekomendasi berdasarkan film tersebut. (6) Permasalahan yang ada pada proses rekomendasi adalah masalah waktu yang diperlukan. Karena 2 hal yang saling terkait dengan proses pembentukan tabel similar items, yaitu (a) pembentukan tabel similar items itu sendiri dan (b) query yang dilakukan terhadap tabel similar items untuk proses pemberian rekomendasi pribadi.

\section{DAFTAR PUSTAKA}

[1] Joe Martin, Brett Tomson, Belajar Sendiri ASP.net dalam 24 jam. Jakarta: Penerbit Andi. 2004.

[2] Siregar, Edison. Membangun Aplikasi Berbasis Web dengan ASP.NET. Gramedia. 2002.

[3] Badrul Sarwar, George Karypis, Joseph Konstan, John Riedl, Item-based Collaborative Filtering Recommendation Algorithms, http://www10.org/cdrom/papers/519/, may 2001

[4] F. Heylighen, Collaborative filtering, http://pespmc1.vub.ac.be/COLLFILT.ht ml, January 2001

[5] Greg Linden, Brent Smith, Jeremy York, Amazon.com Recommendations Item-toItem Collaborative Filterin, February 2003

[6] Linden, Gregory D, Jacobi Jennifer A, Benson Eric A, Collaborative recommendations using item-to-item similarity mapping, http://www.freepatentsonline.com/62666 49.html, April 2001

[7] Stephen Walther, Sams Teach Yourself E-Commerce Programming with ASP in 21 Days, http://www.freebooksclub.net/asp-dotnet/593-sams-teach-yourself-ecommerce-programming-with.html, May 2000 . 